\title{
Synthesis and anion recognition properties of shape-persistent binaphthyl-containing chiral macrocyclic amides
}

\author{
Marco Caricato ${ }^{1}$, Nerea Jordana Leza ${ }^{1}$, Claudia Gargiulli ${ }^{2}$, \\ Giuseppe Gattuso ${ }^{2}$, Daniele Dondi ${ }^{1}$ and Dario Pasini ${ }^{* 1,3}$
}

\section{Full Research Paper}

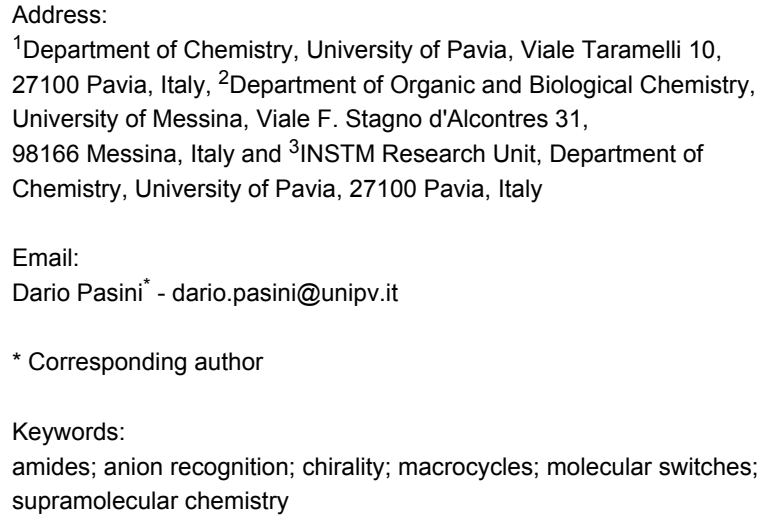

${ }^{1}$ Department of Chemistry, University of Pavia, Viale Taramelli 10, 27100 Pavia, Italy, ${ }^{2}$ Department of Organic and Biological Chemistry, University of Messina, Viale F. Stagno d'Alcontres 31, 98166 Messina, Italy and ${ }^{3}$ INSTM Research Unit, Department of Chemistry, University of Pavia, 27100 Pavia, Italy

Email:

Dario Pasini* - dario.pasini@unipv.it

* Corresponding author

Keywords:

amides; anion recognition; chirality; macrocycles; molecular switches; supramolecular chemistry

\begin{abstract}
We report on the synthesis and characterization of novel shape-persistent, optically active arylamide macrocycles, which can be obtained using a one-pot methodology. Resolved, axially chiral binol scaffolds, which incorporate either methoxy or acetoxy functionalities in the 2,2' positions and carboxylic functionalities in the external 3,3' positions, were used as the source of chirality. Two of these binaphthyls are joined through amidation reactions using rigid diaryl amines of differing shapes, to give homochiral tetraamidic macrocycles. The recognition properties of these supramolecular receptors have been analyzed, and the results indicate a modulation of binding affinities towards dicarboxylate anions, with a drastic change of binding mode depending on the steric and electronic features of the functional groups in the 2,2' positions.
\end{abstract}

\section{Introduction}

Macrocyclic molecules possessing a high degree of shape persistency act as molecular cages, and the scientific interest for such compounds is certainly increasing [1-4]. Support for this statement arises from consideration in two main areas of interest: (a) the recognition properties towards suitable guests

are usually enhanced by limiting the number of conformations accessible to the covalent cyclic structure (resulting in preorganization [5]); (b) shape persistency is a requirement for the formation of organic nanotubes by means of supramolecular organization of macrocycles in the third dimension [6-12]. 
Amide functionalities are hydrogen-bonding tools of widespread use for the conformational stabilization of nanostructures. Noticeable examples can be found in the field of foldamers $[13,14]$ or in the design of assembled architectures functioning as artificial ion-channel mimics [15]. Amide functionalities are also widely used for their hydrogen bonding capability in the context of anion complexation. Several macrocyclic systems capable of effective anion recognition and discrimination have been previously reported [16-18]. Binol (1,1'-binaphthyl-2,2'-diol) based synthons are popular in the recent literature; given their robustness, they are frequently used to impart or transfer chiral information, not only in the field of asymmetric synthesis and catalysis, but also in materials science [19-24].

During the course of our ongoing efforts dealing with the use of binol-based synthons for the production of functional, oriented nanomaterials and chiroptical sensors [25-30], we have reported on the design, synthesis and characterization of a rigid, optically active tetraamidic macrocycle with recognition capabilities towards anions (Figure 1) [31].

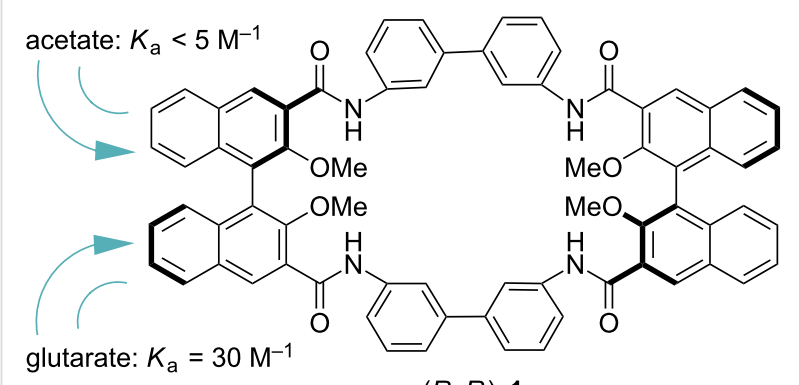

$(R, R)-1$

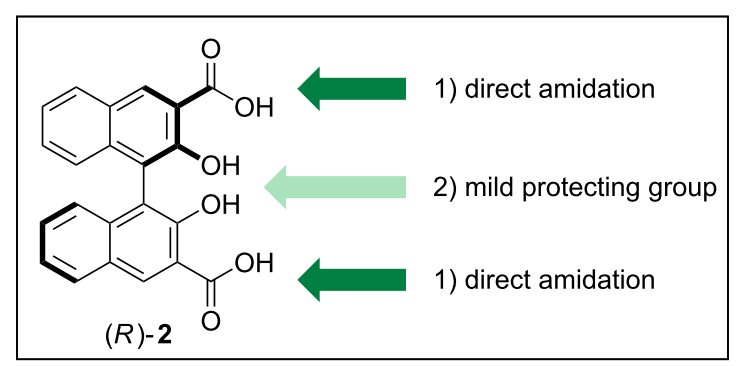

Figure 1: Structure of the macrocycle $(R, R)-1$ (top), and synthetic strategies for the production of novel amide-containing, axially chiral macrocycles (bottom)

In fact, macrocycle $(R, R)-\mathbf{1}$ could be obtained efficiently $(62 \%$ in the macrocyclization step) through a sequential, convergent methodology. It is a 32-membered macrocycle whose cyclic backbone is composed exclusively of $\mathrm{sp}^{2}$-hybridized carbon and nitrogen atoms. An additional internal rigidification of the macrocyclic cavity is given by the presence of stable, sixmembered intramolecular hydrogen bonds between the protected (in the form of methyl ether) phenol moieties in the 2,2' positions and the $\mathrm{NH}$ protons of the amide functionalities in the neighboring 3,3' positions of the binaphthyl units. Macrocycle $(R, R)$-1 showed modest binding affinities towards carboxylate anions, yet detectable binding of proper difunctional carboxylates.

We deemed it to be very interesting to increase the availability of hydrogen-bond donors within the macrocycle cavity, and to unlock the hydrogen-bonding capability of the amide NHs to their full potential for anion recognition. The former could in principle be achieved by unmasking the phenolic oxygen atoms in the $2,2^{\prime}$ positions of the binaphthyl skeletons. As for the latter, the introduction of another protecting group, sterically and electronically modulating the hydrogen-bond accepting capability of the phenolic oxygen, was needed.

In this paper, we present the exploitation of these strategies, resulting in the synthesis and characterization of three novel binaphthyl-based macrocycles, and the evaluation of their potential as supramolecular receptors for aliphatic bidentate carboxylate anions.

\section{Results and Discussion Design, synthesis and spectroscopic charac- terization}

Reactions to deprotect the phenolic oxygens, performed directly on $(R, R)-\mathbf{1}$ as a substrate and attempted under various reaction conditions, proved completely unsuccessful with degradation of the macrocyclic structure occurring in all cases. On the basis of the introductory considerations mentioned earlier, we set out to exploit two orthogonal synthetic strategies (Figure 1, bottom): (1) A direct amidation of the carboxylic acids in the 3,3' positions, in the presence of the free phenolic oxygens in the 2,2' positions. Literature precedents for such amidation using aromatic amines in the presence of vicinal phenol moieties (which compete since they are comparable in nucleophilicity with aromatic amines) are rare [32,33]. As already reported [31], test reactions on model compounds gave disappointing results. The use of benzylic amines, more nucleophilic than arylamines, and therefore competing less with the phenolic moieties in the 2,2' positions, was envisaged as a potential solution and was therefore actively pursued. (2) The use of milder (with respect to methyl ether) protecting groups for the phenolic functionalities in the 2,2' positions; we focused on the use of compound $\mathbf{3}$, bearing acetyl protecting groups, since its synthesis has been reported, and the deprotection of these groups usually occurs under mild basic conditions [34]. Aromatic amines, as in $(R, R)-\mathbf{1}$, could in principle be used. 
Preliminary synthetic work was performed on model compounds to test the reaction conditions. Both enantiomerically pure $(R)-\mathbf{2}$ and $(R)-\mathbf{3}$ and racemic $(R S)$-2 and $(R S)$-3 were used routinely in the experiments described in the following. Regarding approach (1), direct generation of the carboxylic acid chloride (with $\mathrm{SOCl}_{2}$, or oxalyl chloride and DMF; method i), followed by reaction with benzylamine (4a) in the presence of $\mathrm{Et}_{3} \mathrm{~N}$ as the acid scavenger gave compound 5a in excellent yields $(93 \%)$ after purification by column chromatography (Scheme 1). The yield was higher in our hands than the one previously reported [35].<smiles>[R]c1c(C(=O)O)cc2ccccc2c1-c1c([R])c(C(=O)O)cc2ccccc12</smiles>

$2 \mathrm{R}=\mathrm{H}$ $3 \mathrm{R}=\mathrm{COCH}_{3}$

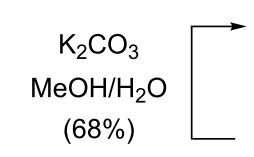

5a $\mathrm{R}=\mathrm{H}($ i $93 \%$; ii $12 \%)$

$5 b \mathrm{R}=\mathrm{H}$

5c $\mathrm{R}=\mathrm{H}$ (i and ii $0 \%)$

6a $\mathrm{R}=\mathrm{COCH}_{3}(\mathrm{i} 0 \%)$

6b R $=\mathrm{COCH}_{3}(\mathrm{i} 37 \%)$

$6 d \mathrm{R}=\mathrm{COCH}_{3}(\mathrm{i} 15 \%)$

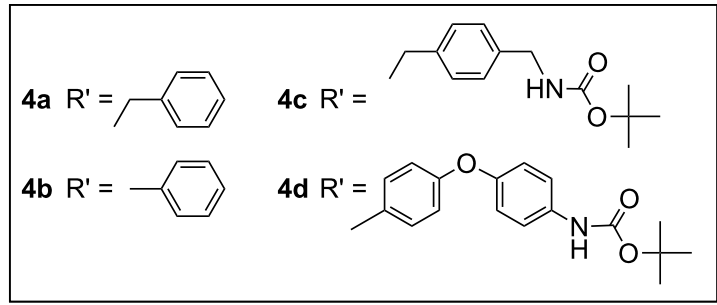

Scheme 1: Reagents and conditions: (i) $\mathrm{SOCl}_{2}, \mathrm{CHCl}_{3}$ or $(\mathrm{COCl})_{2}$ $\mathrm{DMF}, \mathrm{CH}_{2} \mathrm{Cl}_{2}$ then amine, $\mathrm{Et}_{3} \mathrm{~N}, \mathrm{CH}_{2} \mathrm{Cl}_{2}$ or (ii) $\mathrm{CDI}$, THF.
Alternative one-pot amidation procedures, performed directly with the aromatic carboxylic acid and the benzylic amine (method ii) using carbonyldiimidazole (CDI) [36], successfully used by us in the past [29], were instead less than satisfactory. Both protocols were applied with commercially available monoprotected benzylic diamine $\mathbf{4 c}$; in both cases, however, the desired product $\mathbf{5 c}$ could not be isolated. It is likely that the BOC protecting group is not compatible with the presence of the free phenolic groups in our substrates.

Switching to approach (2), when compound 3 was allowed to react with benzylamine $(\mathbf{4 a})$ or aniline $(\mathbf{4 b})$, only the aryl derivate $\mathbf{6 b}$ was obtained in good yield. Compound $\mathbf{6 b}$ could be efficiently deprotected under the reported conditions $\left(\mathrm{K}_{2} \mathrm{CO}_{3} /\right.$ $\mathrm{MeOH}$ ) to give $\mathbf{5 b}$. When the monoprotected aryl amine $\mathbf{4 d}$ was allowed to react with compound $\mathbf{3}$ using the same reaction conditions, however, compound $\mathbf{6 d}$ could not be efficiently synthesized. The low yield obtained in this step discouraged us from pursuing a stepwise methodology for the macrocyclization, which had been used in the case of $(R, R)-1$ [31].

In order to quickly evaluate the potential of acetyl-protected tetraamidic macrocyles as analogues of $(R, R)-\mathbf{1}$, we proceeded to directly cyclize equimolar amounts of optically pure, resolved $(R)-\mathbf{3}$ (via formation of the corresponding diacyl chloride) and commercially available diaryl amines $\mathbf{8}$ and $\mathbf{9}$, under classical high-dilution conditions [13] which were successful for the synthesis of compound $\mathbf{6 b}$. Indeed, homochiral macrocycles $(R, R)-\mathbf{1 0},(R, R)-\mathbf{1 1}$ and $(R, R)-\mathbf{1 2}$ could be isolated after extensive purification by column chromatography, although in disappointingly low yields $(0-5 \%$ isolated yield, Scheme 2$)$.

Furthermore, macrocycle $(R, R)-\mathbf{1 3}$ could not be isolated at all. The low quantities of macrocycles $(R, R)-\mathbf{1 0}$ and $(R, R)-\mathbf{1 1}$ obtained prevented us from exploring the cleavage of the acetyl functionalities.<smiles>[R]c1c(C(=O)O)cc2ccccc2c1-c1c([R])c(C(=O)O)cc2ccccc12</smiles>

$(R)-3 \mathrm{R}=\mathrm{COCH}_{3}$ (R) $-7 \mathrm{R}=\mathrm{CH}_{3}$

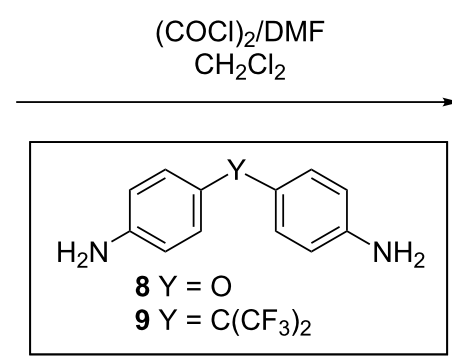

$\mathrm{Et}_{3} \mathrm{~N} / \mathrm{CH}_{2} \mathrm{Cl}_{2}$ high dilution<smiles>[R]Oc1c(C(=O)Nc2ccc([Y])cc2)cc2ccccc2c1-c1c([R])c(C(=O)Nc2ccc([Y])cc2)cc2cc(C(=O)Nc3ccc([Y])cc3)c([R])c(-c3c([R])c(C(=O)Nc4ccc([Y])cc4)cc4ccccc34)c12</smiles>

$\begin{array}{lll}(R, R)-10 & \mathrm{R}=\mathrm{COCH}_{3} \mathrm{Y}=\mathrm{O} & (4 \%) \\ (R, R)-11 \quad \mathrm{R}=\mathrm{COCH}_{3} \mathrm{Y}=\mathrm{C}\left(\mathrm{CF}_{3}\right)_{2} & (4 \%) \\ (R, R)-12 & \mathrm{R}=\mathrm{CH}_{3} \quad \mathrm{Y}=\mathrm{O} & (5 \%) \\ (R, R)-13 \mathrm{R}=\mathrm{CH}_{3} \quad \mathrm{Y}=\mathrm{C}\left(\mathrm{CF}_{3}\right)_{2} & (0 \%)\end{array}$ 
${ }^{1} \mathrm{H}$ NMR spectra for all compounds were relatively simple (see Experimental and Supporting Information File 1), reflecting the structural symmetry found in precursors $\left(C_{2}\right.$ molecular symmetry) and in homochiral macrocycles 10-12 $\left(D_{2}\right.$ molecular symmetry). The peaks for the NH proton resonances of the amide functionalities are sharp in S(6)-type [37] hydrogenbonded systems, such as those between the NH and the neighboring methoxy groups in $(R, R)-\mathbf{1}$ and $(R, R)-\mathbf{1 2}$. The NH proton resonances, however, could not be assigned either in the series of compounds $\mathbf{5}$, or in the acetoxy protected compounds $\mathbf{6}$ and macrocycles 10,11, as they are broad or below the baseline, so as to indicate unlocked (thus potentially more available to incoming guests), conformationally mobile NH groups (Table 1).

There are also substantial differences in the resonances of the $\mathrm{H}$ 4,4 ' protons of the binaphthyl skeleton, which are usually most sensitive to variations in the substitution pattern (and thus, in the electronic structure) within the naphthyl systems of the binaphthyl units.

The UV-vis spectra of macrocycles $(R, R)-\mathbf{1 0}$ and $(R, R)-\mathbf{1 1}$, recorded in solvents possessing different solvating and hydrogen-bonding abilities $\left(\mathrm{CH}_{2} \mathrm{Cl}_{2}, \mathrm{EtOH}\right)$, showed little solvent dependence, with $\lambda_{\max }$ around $230 \mathrm{~nm}$ in all cases, and with well-defined shoulders just below $300 \mathrm{~nm}$. Comparison with data available on parent systems [31] reveals that the spectra cannot be explained as the sum of those generated by the two major aromatic chromophoric components (the naphthyl rings of the binaphthyl units and the aryl moieties of the spacing units); electronic communication between them is present (Figure 2).

It is interesting to note how the spectra of macrocycle $(R, R)-\mathbf{1 2}$, bearing methoxy protected phenols, showed the most

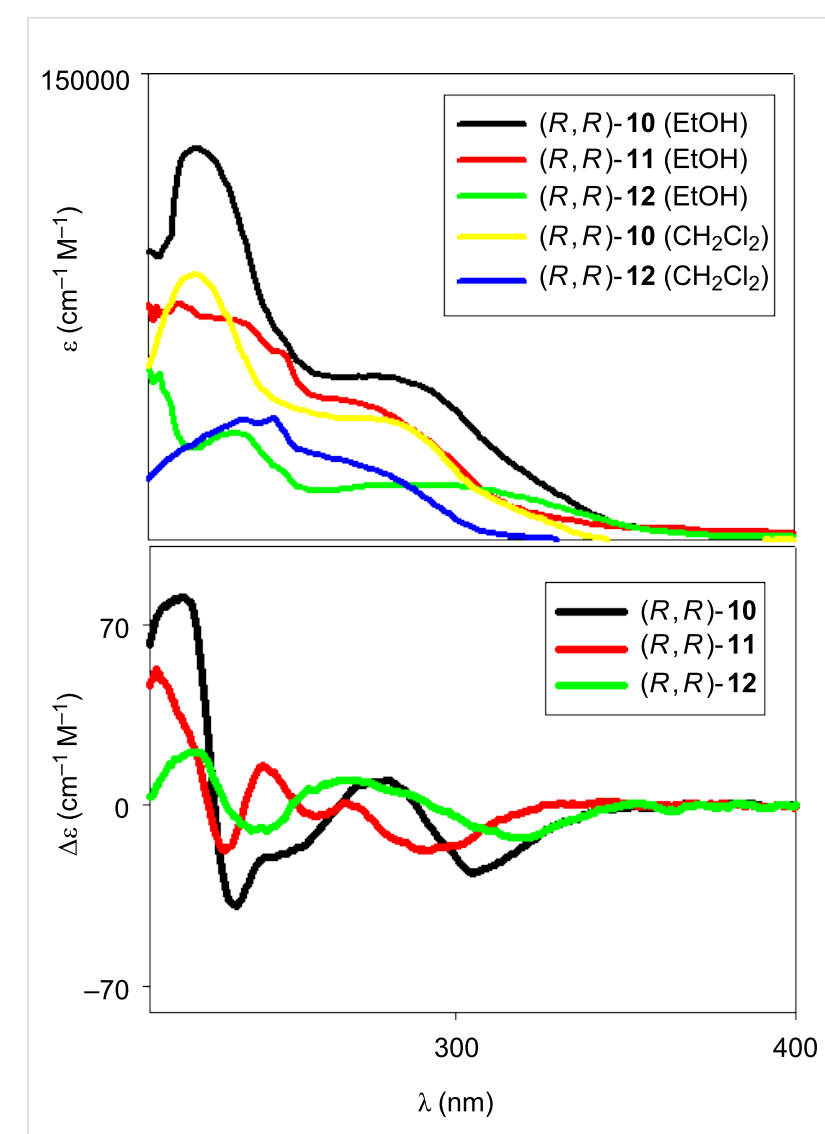

Figure 2: UV and CD (EtOH) spectra of macrocycles $(R, R)-10$, $(R, R)-11$ and $(R, R)-12$ in the range $220-400 \mathrm{~nm}$.

bathochromically shifted shoulder, centered at $320 \mathrm{~nm}$ (quite different from $(R, R)-10$ ). The CD spectra (in EtOH) show activity associated with all active UV chromophores and more marked activity for the macrocycle $(R, R)-\mathbf{1 0}$, with exciton couplet signals greater in intensity than the ones of the other macrocycles.

Table 1: Selected chemical shifts for compounds in $\mathrm{CDCl}_{3}\left(25^{\circ} \mathrm{C}\right) .^{\text {a }}$

\begin{tabular}{|c|c|c|c|c|c|c|}
\hline Entry & Compound & $\mathrm{NH}$ & Binol-H 4,4'b & $\mathrm{OCH}_{3}$ & $\mathrm{COCH}_{3}$ & $\mathrm{OH}$ \\
\hline 1 & $5 a$ & 9.88 & 8.74 & - & - & 12.44 \\
\hline 2 & $5 b$ & n. d. ${ }^{c}$ & 8.85 & - & - & 10.31 \\
\hline 4 & $6 b$ & n. d. & 8.47 & - & 1.83 & - \\
\hline 5 & $6 d$ & n. d. & 8.46 & - & 1.84 & - \\
\hline 6 & $(R, R)-10$ & n. d. & 8.58 & - & 1.82 & - \\
\hline 7 & $(R, R)-11$ & n. d. & 8.58 & - & 1.83 & - \\
\hline 8 & $(R, R)-12$ & 10.45 & 9.06 & 3.32 & - & - \\
\hline 9 & $(R, R)-1$ & 10.00 & 9.00 & 3.53 & - & - \\
\hline
\end{tabular}

aAll spectra recorded at 5-10 $\mathrm{mM}$ sample concentration. ${ }^{\text {b }}$ Resonances related to the singlet corresponding to the proton in the 4,4 ' positions of the binol skeleton. ${ }^{\mathrm{n}} \mathrm{n} . \mathrm{d} . \mathrm{=}$ broad or not identified. 


\section{Molecular modeling}

Molecular modeling was performed on the structures of macrocycles $(R, R)-\mathbf{1 0},(R, R)-\mathbf{1 1}$ and $(R, R)-\mathbf{1 2}$, and on the hypothetical macrocycle $(R, R)-\mathbf{1 3}$, in order to have an estimate of macrocyclic cavities, and to gather information on the relative orientation of the functional groups involved in the binding phenomena. Preliminary conformational structures were optimized by using the semiempirical PM3 method [38]. The geometries were then subjected to further refinement by using DFT B3LYP/6-31G(d) methods. In order to locate conformers having the minimum energy, the structures obtained by preliminary optimization were then subjected to molecular dynamics cycles and subsequent reoptimization [28]. The most stable minimized structures of the macrocycles are shown in Figure 3 , in which the distances between the four hydrogen atoms of the $\mathrm{NH}$ amide groups within each macrocycle are reported (in angstroms).

The two macrocycles bearing aryloxy ether spacers $((R, R)-\mathbf{1 0}$ and $(R, R)-12)$ have a rectangular overall geometry, probably as a consequence of the imposed dihedral angle of the oxygen atom bridges. In fact, the two trifluoromethyl-containing macrocycles $((R, R)$-11 and $(R, R)$-13) have a more square-like geometry, which seems to be associated with the smaller imposed angle of the $\mathrm{sp}^{3}$-hybridized carbon atom in the spacing units. The dimensions of the macrocycles are essentially identical for the homologous sets of $(R, R)-\mathbf{1 1}$ and $(R, R)-\mathbf{1 3}(14 \AA \times 15.7 \AA)$, and of $(R, R)-\mathbf{1 0}$ and $(R, R)-\mathbf{1 2}(12.5 \AA \times 16.2 \AA)$. In the case of $(R, R)-\mathbf{1}$, the macrocycle cavity is more square-like, with the four amides all at a quite similar distance (ca. 6-7 $\AA$ ). In the case of 10-13, however, there is a substantial differentiation in distances between the two sets of amide functionalities, those linked to each different binaphthyl unit within the macrocycle. $(R, R)$-11 and $(R, R)-\mathbf{1 3}$ possess slightly less distorted molecular conformations in which a $C_{2}$ overall molecular symmetry seems to be retained. In fact, the dihedral angles of the binaphthyl units within the macrocycle are identical in the case of $(R, R)-\mathbf{1 1}$ $\left(76.1^{\circ}\right)$ and of $(R, R)-\mathbf{1 3}\left(79.5^{\circ}\right)$, whereas they differ slightly in the case of the more distorted $(R, R)-10$ (70.8 and 72.6 $)$ and $(R, R)-12\left(85.9\right.$ and $\left.85.6^{\circ}\right)$. Molecular modeling does not give clear hints as to why macrocycle $(R, R)-\mathbf{1 3}$ could not be obtained.
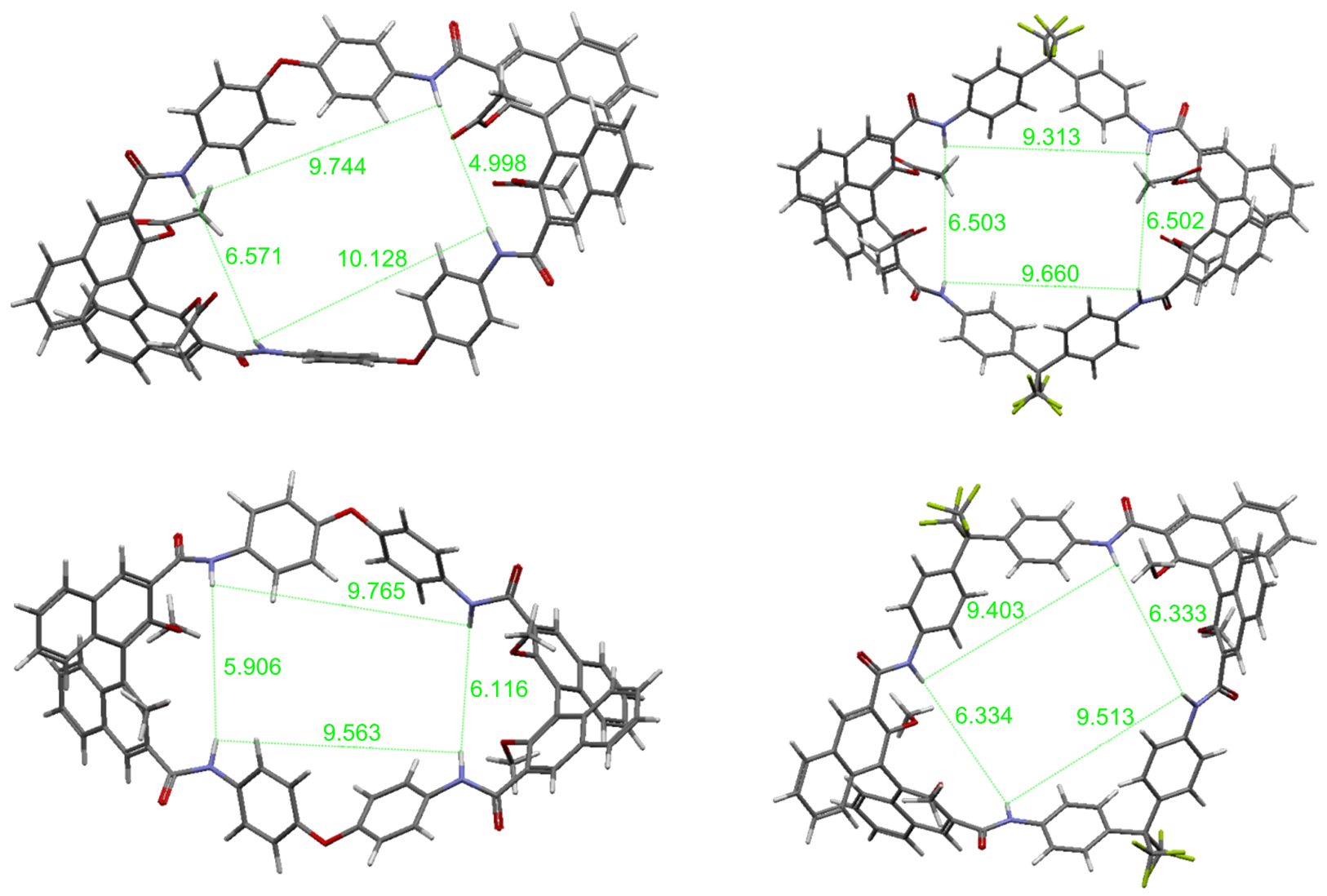

Figure 3: Minimized molecular structures of (from top left to bottom left, clockwise): $(R, R)-10,(R, R)-11,(R, R)-13$ and $(R, R)-12$ (distances between the $\mathrm{H}$ atoms of the $\mathrm{NH}$ amide groups are given in angstroms). 
The shortest distances between the symmetry-related $\mathrm{NH}$ groups, shown in Figure 3, are compatible with the insertion of either glutarate or succinate. In fact, the calculated dimensions of the two carboxylates are $5.3 \AA$ for succinate and $6.5 \AA$ for glutarate, considering their fully extended conformation. These data rationalize the preference shown in the case of macrocycle 12 for succinate; in detail, they suggest that the binding mode involves two NH groups linked to the same binaphthyl unit, rather than a complexation mode in which the bidentate guests are extended across the cavities of the macrocycles. These findings also explain why, in the presence of bulkier acetoxy groups on the binaphthyl units, this recognition mechanism in $\mathbf{1 0}$ and $\mathbf{1 1}$ is suppressed and alternative mechanisms take place (see below).

\section{Complexation studies}

${ }^{1} \mathrm{H}$ NMR titration experiments showed that the addition of anionic guests, in the form of their tetrabutylammonium salts, produced progressive chemical-shift variations, along with a broadening of the peaks belonging to the amide $\mathrm{NH}$ protons, indicating that these groups were engaged in hydrogen bonding with the carboxylate guests with a fast-exchanging equilibrium on the NMR time scale. Complexation-induced shifts on other resonances of the binaphthyl residues (Figure 4) indicated, as expected, a change of the electronic structure of these units upon complexation; these peaks were used for the calculation of the association constants, by using a 1:1 model equation (see Experimental).

Alternative binding models (i.e., stoichiometries) produced much poorer and hence unacceptable fitting of the titration data. In the case of $(R, R)$-12, we examined dicarboxylate anions such as glutarate and succinate, in order to have a direct point of comparison with $(R, R)-\mathbf{1}$ (Table 2).

\begin{tabular}{|c|c|c|c|}
\hline Entry & Macrocycle & Succinate & Glutarate \\
\hline 1 & $(R, R)-12$ & $34 \pm 3$ & $21 \pm 13$ \\
\hline $2^{b}$ & $(R, R)-1$ & n. d. & $30 \pm 12$ \\
\hline
\end{tabular}

aMeasured by ${ }^{1} \mathrm{H}$ NMR $\left(500 \mathrm{MHz}, 298 \mathrm{~K}, \mathrm{CDCl}_{3}\right)$ using tetrabutylammonium salts. ${ }^{b}$ Data taken from Ref. [31]; n. d. = not determined.

Succinate was found to bind better than glutarate to macrocycle $(R, R)-12$, probably as its length is more suited than glutarate to

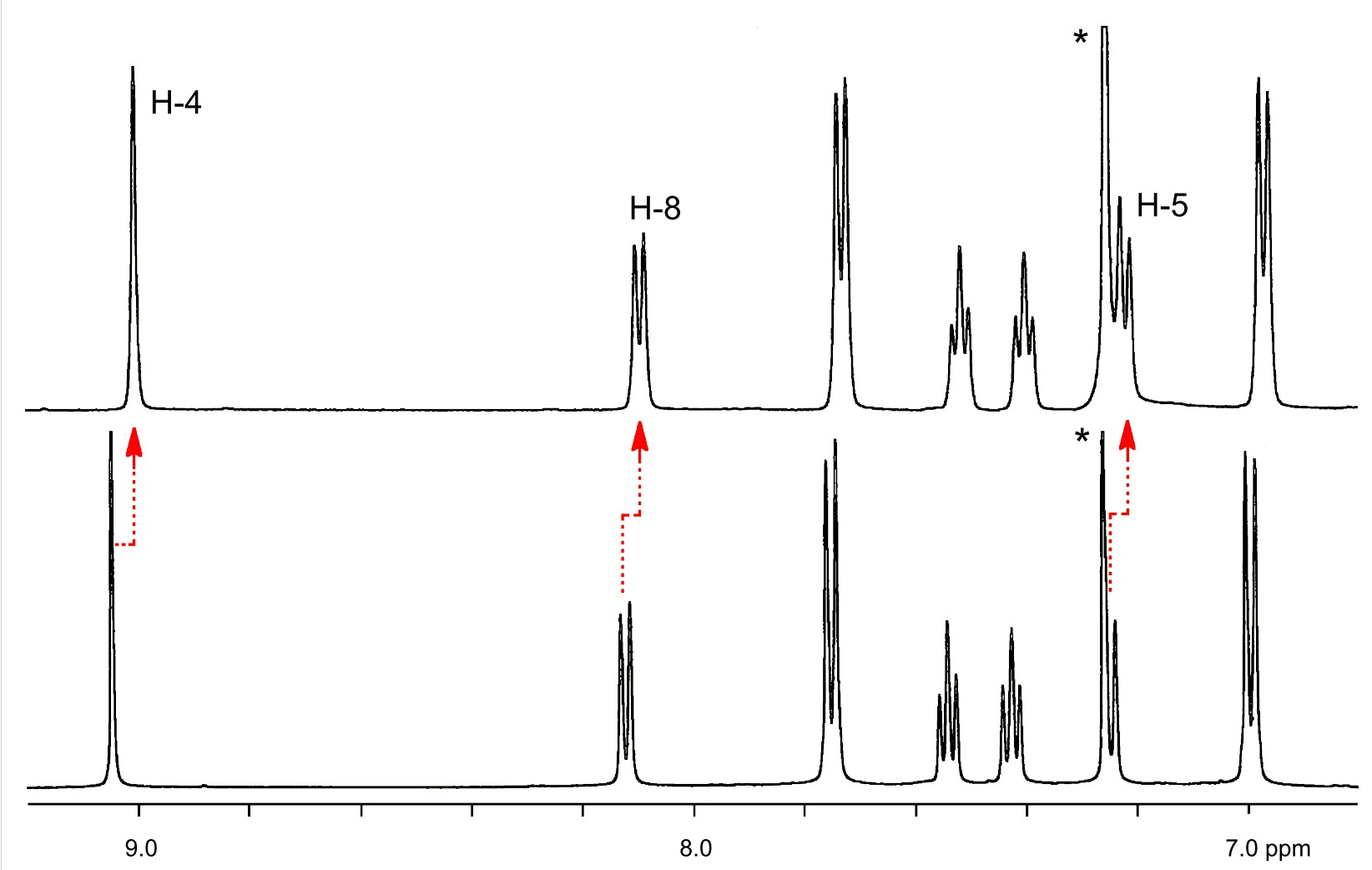

Figure 4: Aromatic region of the ${ }^{1} \mathrm{H} \mathrm{NMR}\left(\mathrm{CDCl}_{3}, 500 \mathrm{MHz}, 25^{\circ} \mathrm{C}\right)$ spectra of macrocycle $(R, R)-12(2.8 \mathrm{mM}$, bottom $)$ and at the end of the titration with tetrabutylammonium succinate $\left([(R)-7]=2.8 \mathrm{mM},\left[\left(\mathrm{CH}_{2} \mathrm{CO}_{2}\right)_{2}\left(\mathrm{Bu}_{4} \mathrm{~N}\right)_{2}\right]=28 \mathrm{mM}\right.$, top). Asterisks indicate the residual solvent peaks. 
fit into the cavity of $\mathbf{1 2}$ by interacting simultaneously with two different $\mathrm{NH}$ groups placed on the same binaphthyl residue (see above, molecular modeling), possibly in a cooperative fashion [39].

Similar titrations were carried out on $(R, R)-\mathbf{1 0}$ and $(R, R)-\mathbf{1 1}$, bearing acetoxy substituents in the $2,2^{\prime}$ positions of the binaphthyl skeletons, which are certainly bulkier than the methoxy substituents present in $(R, R)-\mathbf{1 2}$. A very different behavior was observed for both macrocycles: The ${ }^{1} \mathrm{H}$ NMR spectra in $\mathrm{CDCl}_{3}$, upon addition of both anionic guests, became very complex, with a complete loss of the initial symmetry. From the preliminary data in our hands, it is clear that there is a slow-exchanging equilibrium on the NMR time scale: the bulkier acetoxy group presumably inhibits a binding mechanism based on a fast host-guest exchange. A slow encapsulation mechanism, with multiple modes of binding of the difunctional anionic guests within the macrocycle, or the formation of aggregates of several macrocyclic units, held by the bifunctional anionic guests binding to a single amide of each macrocycle, cannot be ruled out at the present stage. Further studies are in progress to unravel the behavior of these acetoxy-bearing macrocycles.

\section{Conclusion}

We have reported the synthesis and characterization of three novel homochiral macrocycles, built upon resolved 1,1'-binaphthyl scaffolds, which incorporate either methoxy or acetoxy functionalities in the 2,2' positions, and carboxylic functionalities in the external 3,3' positions. After evaluation of the synthetic strategy through test reactions on model compounds, the macrocycles were obtained through one-pot amidation reactions by using two different rigid diarylamines and highdilution conditions, although in low isolated yields $(0-5 \%)$. The macrocycle bearing less sterically demanding methoxy substituents is an effective supramolecular receptor for dicarboxylate anions, with a preference for glutarate $\left(K_{\mathrm{a}}=34 \mathrm{M}^{-1}\right.$ for the 1:1 complex in $\mathrm{CDCl}_{3}$ ), as measured by ${ }^{1} \mathrm{H}$ NMR spectroscopy. With the acetoxy groups installed within the macrocyclic framework, a drastic change of binding mode occurs, with slow aggregation equilibria on the NMR time scale.

\section{Experimental}

General. All commercially available compounds were purchased from commercial sources and used as received. Racemic or ( $R$ )-2 [40,41], racemic or $(R)-\mathbf{3}$ [42], 4c [43], 4d [44] and $(R)-7$ [45] were prepared according to literature procedures. THF (Na), $\mathrm{CH}_{2} \mathrm{Cl}_{2}\left(\mathrm{CaH}_{2}\right)$ and $\mathrm{CHCl}_{3}(4 \AA$ molecular sieves) were dried before use. Analytical thin-layer chromatography was performed on silica gel, chromophore-loaded, commercially available plates. Flash chromatography was carried out by using silica gel (pore size $60 \AA, 230-400$ mesh).
${ }^{1} \mathrm{H}$ and ${ }^{13} \mathrm{C}$ NMR spectra were recorded from solutions in $\mathrm{CDCl}_{3}$ on a 200,300 or $500 \mathrm{MHz}$ spectrometer with the solvent residual proton signal or tetramethylsilane as the standard. The UV-vis spectroscopic studies were recorded by using commercially available spectrophotometers. Mass spectra were recorded by using an electrospray ionization instrument. Optical rotations were measured on a polarimeter with a sodium lamp $(\lambda=589 \mathrm{~nm})$ and are reported as follows: $[\alpha]_{\mathrm{D}}{ }^{\mathrm{rt}}(c=\mathrm{g}(100 \mathrm{~mL}$ solution $)^{-1}$ ). CD spectroscopy was performed by using a spectropolarimeter; spectra were recorded at $25{ }^{\circ} \mathrm{C}$ at a scanning speed of $50 \mathrm{~nm} \mathrm{~min}{ }^{-1}$ and were background corrected.

Compound 5a [35]. $\mathrm{SOCl}_{2}(1.1 \mathrm{~mL})$ was added to a solution of compound $(R S)-2\left(250 \mathrm{mg}, 0.67 \mathrm{mmol}, 1\right.$ equiv) in dry $\mathrm{CHCl}_{3}$ $(10 \mathrm{~mL})$ and the solution was heated under reflux overnight. Then, the solution was concentrated in vacuo and the crude product was added to a solution of benzylamine cooled to $0{ }^{\circ} \mathrm{C}$ (430 mg, $4.00 \mathrm{mmol}, 6$ equiv) in dry $\mathrm{CH}_{2} \mathrm{Cl}_{2}(10 \mathrm{~mL})$. After being stirred overnight at $\mathrm{rt}$, the reaction mixture was quenched with $1 \mathrm{M} \mathrm{HCl}(30 \mathrm{~mL})$, extracted with $\mathrm{CH}_{2} \mathrm{Cl}_{2}(3 \times 25 \mathrm{~mL})$, and dried $\left(\mathrm{Na}_{2} \mathrm{SO}_{4}\right)$. The solution was filtered and concentrated in vacuo to yield pure 5a (340 mg, 93\%). ${ }^{1} \mathrm{H} \mathrm{NMR}\left(\mathrm{CDCl}_{3}\right.$, $\left.300 \mathrm{MHz}, 25{ }^{\circ} \mathrm{C}\right) \delta 12.44(\mathrm{~s}, 2 \mathrm{H}, \mathrm{OH}), 9.88$ (s, 2H, NH), 8.74 (s, 2H, binaphthyl), 7.91 (d, 2H, binaphthyl), 7.37 (m, 14H, phenyl + binaphthyl), 6.98 (d, 2H, binaphthyl), $4.60\left(\mathrm{~d}, \mathrm{CH}_{2}\right)$. Alternative method: A solution of CDI $(162 \mathrm{mg}, 2.01 \mathrm{mmol}$, 3 equiv) in THF (12 mL) was added to a solution of $(R)-2$ ( $250 \mathrm{mg}, 0.668 \mathrm{mmol}, 1$ equiv) in THF $(20 \mathrm{~mL})$. The solution was stirred for $1.5 \mathrm{~h}$ at $\mathrm{rt}$, and then a solution of benzylamine $(0.146 \mathrm{~mL}, 1.34 \mathrm{mmol}, 2$ equiv) in THF (12 mL) was added and the mixture was stirred for $15 \mathrm{~h}$. The reaction mixture was concentrated in vacuo, and the crude product was purified by column chromatography (hexane/AcOEt 9:1) to yield 5a (44 mg, 12\%).

Compound 6b. $(\mathrm{COCl})_{2}(0.137 \mathrm{~mL}, 1.57 \mathrm{mmol}, 8$ equiv $)$ and one drop of DMF were added to a solution of compound $(R)-3$ (90 mg, $0.196 \mathrm{mmol}, 1$ equiv) and dry $\mathrm{CH}_{2} \mathrm{Cl}_{2}(10 \mathrm{~mL})$. The solution was heated under reflux for $2 \mathrm{~h}$. After $1 \mathrm{~h}$ at $\mathrm{rt}$ the solution was concentrated in vacuo, the crude product was dissolved in dry $\mathrm{CH}_{2} \mathrm{Cl}_{2}(5 \mathrm{~mL})$, and a solution of $4 \mathbf{b}(0.045 \mathrm{~mL}$, $0.49 \mathrm{mmol}, 2.5$ equiv) and $\mathrm{Et}_{3} \mathrm{~N}(0.082 \mathrm{~mL}, 0.59 \mathrm{mmol}$, 3 equiv) in dry $\mathrm{CH}_{2} \mathrm{Cl}_{2}(5 \mathrm{~mL})$ was added. The resulting solution was heated under reflux for $2 \mathrm{~h}$. After cooling, the reaction mixture was quenched with brine $(20 \mathrm{~mL})$, extracted with $\mathrm{CH}_{2} \mathrm{Cl}_{2}(3 \times 25 \mathrm{~mL})$, and dried $\left(\mathrm{Na}_{2} \mathrm{SO}_{4}\right)$. The crude product was purified by column chromatography (hexane/AcOEt 8:2 to 7:3) to yield $\mathbf{6 b}(44 \mathrm{mg}, 37 \%) .{ }^{1} \mathrm{H} \mathrm{NMR}\left(\mathrm{CDCl}_{3}, 300 \mathrm{MHz}\right.$, $\left.25^{\circ} \mathrm{C}\right) \delta 8.47$ (s, 2H, binaphthyl), 8.10 (s, 2H, binaphthyl), 8.03 $(\mathrm{m}, 2 \mathrm{H}$, phenyl), $7.60(\mathrm{~m}, 6 \mathrm{H}$, binaphthyl + phenyl), $7.37(\mathrm{~m}$, $4 \mathrm{H}$, binaphthyl), $7.22\left(\mathrm{~m}, 4 \mathrm{H}\right.$, phenyl), $1.83\left(\mathrm{~s}, 6 \mathrm{H},-\mathrm{COCH}_{3}\right)$. 
Compound 5b. $\mathrm{K}_{2} \mathrm{CO}_{3}$ (91 mg, 0.66 mmol, 8 equiv) and $\mathrm{H}_{2} \mathrm{O}$ $(10 \mathrm{~mL})$ were added to a solution of compound $\mathbf{6 b}(44 \mathrm{mg}$, $0.082 \mathrm{mmol}, 1$ equiv) and $\mathrm{CH}_{3} \mathrm{OH}(10 \mathrm{~mL})$. Then, the solution was stirred for $4 \mathrm{~h}$ at $\mathrm{rt}$. The reaction mixture was quenched with $1 \mathrm{M} \mathrm{HCl}$, extracted with $\mathrm{CH}_{2} \mathrm{Cl}_{2}$ and dried $\left(\mathrm{Na}_{2} \mathrm{SO}_{4}\right)$. The solution was filtered and concentrated in vacuo and the crude product was purified by column chromatography (hexane/ AcOEt 7:3) to yield 5b $(25 \mathrm{mg}, 68 \%) .{ }^{1} \mathrm{H} \mathrm{NMR}\left(\mathrm{CDCl}_{3}\right.$, $\left.300 \mathrm{MHz}, 25^{\circ} \mathrm{C}\right) \delta 10.31$ (brs, $\left.2 \mathrm{H}, \mathrm{OH}\right), 8.85$ (s, 2H, binaphthyl), 7.97 (m, 2H, binaphthyl), 7.82 (m, 4H, phenyl), 7.40 (m, $8 \mathrm{H}$, binaphthyl + phenyl), $7.17(\mathrm{~m}, 4 \mathrm{H}$, binaphthyl). The data are consistent with those reported in the literature [46].

Compound 6d. $(\mathrm{COCl})_{2}(0.28 \mathrm{~mL}, 3.21 \mathrm{mmol}, 8$ equiv) and one drop of DMF were added to a solution of compound 3 (184 mg, $0.402 \mathrm{mmol}, 1$ equiv) and dry $\mathrm{CH}_{2} \mathrm{Cl}_{2}(15 \mathrm{~mL}$ ). Then, the solution was heated at reflux for $2 \mathrm{~h}$. After $1 \mathrm{~h}$ at $\mathrm{rt}$ the solution was concentrated in vacuo and the crude product was dissolved in dry $\mathrm{CH}_{2} \mathrm{Cl}_{2}(10 \mathrm{~mL})$. This solution and a solution of $\mathbf{4 d}$ (300 mg, $1 \mathrm{mmol}, 2.5$ equiv) in dry $\mathrm{CH}_{2} \mathrm{Cl}_{2}(10 \mathrm{~mL})$ were added dropwise at the same rate over a period of $1 \mathrm{~h}$ to a solution of $\mathrm{Et}_{3} \mathrm{~N}\left(0.279 \mathrm{~mL}, 2 \mathrm{mmol}, 5\right.$ equiv) in dry $\mathrm{CH}_{2} \mathrm{Cl}_{2}$ $(10 \mathrm{~mL})$. The resulting solution was heated under reflux for $2 \mathrm{~h}$. After cooling, the reaction mixture was quenched with brine $(20 \mathrm{~mL})$, extracted with $\mathrm{CH}_{2} \mathrm{Cl}_{2}(3 \times 25 \mathrm{~mL})$ and dried $\left(\mathrm{Na}_{2} \mathrm{SO}_{4}\right)$. The crude product was purified by column chromatography $\left(\mathrm{CH}_{2} \mathrm{Cl}_{2} / \mathrm{AcOEt} 10: 0\right.$ to $\left.9: 1\right)$ to yield $\mathbf{6 d}(61 \mathrm{mg}$, $15 \%) .{ }^{1} \mathrm{H} \mathrm{NMR}\left(\mathrm{CDCl}_{3}, 300 \mathrm{MHz}, 25{ }^{\circ} \mathrm{C}\right) \delta 8.46(\mathrm{~s}, 2 \mathrm{H}$, binaphthyl), 8.04 (s, 4H, binaphthyl), 7.56 (d, 6H, binaphthyl + phenyl), 7.35 (m, 6H, binaphthyl + phenyl), $6.97(\mathrm{~d}, 8 \mathrm{H}$, phenyl), $1.84\left(\mathrm{~s}, 6 \mathrm{H},-\mathrm{COCH}_{3}\right), 1.53(\mathrm{~s}, 18 \mathrm{H}, t-\mathrm{Bu})$.

Macrocycle $(\boldsymbol{R}, \boldsymbol{R})-10 .(\mathrm{COCl})_{2}(0.381 \mathrm{~mL}, 4.38 \mathrm{mmol}, 8$ equiv $)$ and one drop of DMF were added to a solution of compound (R)-3 (250 mg, $0.546 \mathrm{mmol}, 1$ equiv) in dry $\mathrm{CH}_{2} \mathrm{Cl}_{2}(20 \mathrm{~mL})$. The solution was heated under reflux for $2 \mathrm{~h}$. After $1 \mathrm{~h}$ at $\mathrm{rt}$ the solvent was removed in vacuo and the crude product was dissolved in dry $\mathrm{CH}_{2} \mathrm{Cl}_{2}(35 \mathrm{~mL})$. This solution and a solution of 8 (109 mg, $0.546 \mathrm{mmol}, 1$ equiv) in dry $\mathrm{CH}_{2} \mathrm{Cl}_{2}(35 \mathrm{~mL})$ were added dropwise at the same rate over a period of $1 \mathrm{~h}$ to a solution of $\mathrm{Et}_{3} \mathrm{~N}$ (0.228 mL, $1.64 \mathrm{mmol}, 3$ equiv) in dry $\mathrm{CH}_{2} \mathrm{Cl}_{2}$ $(35 \mathrm{~mL})$. The resulting solution was heated under reflux overnight. After cooling, the reaction mixture was quenched with brine $(50 \mathrm{~mL})$, extracted with $\mathrm{CH}_{2} \mathrm{Cl}_{2}(3 \times 50 \mathrm{~mL})$ and dried $\left(\mathrm{Na}_{2} \mathrm{SO}_{4}\right)$. The solution was filtered and concentrated in vacuo, and the crude product was purified by column chromatography $\left(\mathrm{CH}_{2} \mathrm{Cl}_{2} / \mathrm{AcOEt} 9: 1\right)$ to yield $(R, R)-10$ (7 mg, 4\%). $[\alpha]_{\mathrm{D}}{ }^{25}+101^{\circ}\left(c 0.001, \mathrm{CH}_{2} \mathrm{Cl}_{2}\right) ;{ }^{1} \mathrm{H} \mathrm{NMR}\left(\mathrm{CDCl}_{3}, 75 \mathrm{MHz}\right.$, $\left.25{ }^{\circ} \mathrm{C}\right) \delta 8.58(\mathrm{~s}, 4 \mathrm{H}$, binaphthyl), $8.05(\mathrm{~m}, 8 \mathrm{H}$, phenyl), 7.50 (m, 16H, binaphthyl + phenyl), 6.97 (d, 8H, binaphthyl), 1.82 (s, $\left.12 \mathrm{H},-\mathrm{COCH}_{3}\right) ;{ }^{13} \mathrm{C} \mathrm{NMR}\left(\mathrm{CDCl}_{3}, 75 \mathrm{MHz}, 25^{\circ} \mathrm{C}\right) \delta 168.7$
$(\mathrm{O}-\underline{\mathrm{CqOCH}} 3), 163.5(\mathrm{O}-\underline{\mathrm{CqON}}), 154.6(\mathrm{Cq}), 143.1(\mathrm{Cq}), 133.8$ $(\mathrm{Cq}), 133.3(\mathrm{CH}), 131.2(\mathrm{Cq}) 131.0(\mathrm{Cq}), 129.0(\mathrm{CH}), 128.7$ $(2 \mathrm{CH}), 128.0(\mathrm{Cq}), 127.0(\mathrm{CH}), 126.4(\mathrm{CH}), 125.1(\mathrm{Cq}), 121.1$ $(\mathrm{CH}), 119.7(2 \mathrm{CH}), 20.4\left(\mathrm{COC}_{3}\right)_{3}$; ESIMS m/z: 1267.5 $\left([\mathrm{M}+\mathrm{Na}]^{+}, 100 \%\right)$.

Macrocycle $(\boldsymbol{R}, \boldsymbol{R})-11$. The title compound was prepared by following the same procedure used for $\mathbf{1 0}$ but with diamine $\mathbf{9}$ used instead of $\mathbf{8}$. The crude product was purified by column chromatography $\left(\mathrm{CH}_{2} \mathrm{Cl}_{2} / \mathrm{AcOEt} 98: 2\right)$ to yield $(R, R)-\mathbf{1 1}$ $(18 \mathrm{mg}, 4 \%) \cdot[\alpha]_{\mathrm{D}}{ }^{25}+56^{\circ}\left(c 0.0015, \mathrm{CH}_{2} \mathrm{Cl}_{2}\right) ;{ }^{1} \mathrm{H} \mathrm{NMR}$ $\left(\mathrm{CDCl}_{3}, 75 \mathrm{MHz}, 25^{\circ} \mathrm{C}\right) \delta 8.58(\mathrm{~s}, 4 \mathrm{H}$, binaphthyl), $8.25(\mathrm{~s}, 4 \mathrm{H}$, phenyl), 8.07 (d, 4H, phenyl), $7.40(\mathrm{~m}, 24 \mathrm{H}$, binaphthyl + phenyl), $1.83\left(\mathrm{~s}, 12 \mathrm{H}, \mathrm{COCH}_{3}\right) ;{ }^{13} \mathrm{C} \mathrm{NMR}\left(\mathrm{CDCl}_{3}, 75 \mathrm{MHz}\right.$, $\left.25^{\circ} \mathrm{C}\right) \delta 168.9\left(\mathrm{O}-\underline{\mathrm{CqOCH}_{3}}\right), 163.8(\mathrm{O}-\underline{\mathrm{CqON}}), 143.0(\mathrm{Cq})$, $138.1(\mathrm{Cq}), 133.9(\overline{\mathrm{Cq}}), 131.3(\mathrm{CH}), 131.1(2 \mathrm{CH}), 130.9(\mathrm{Cq})$, $129.6(\mathrm{Cq}), 129.0(\mathrm{CH}), 128.9(\mathrm{CH}), 127.9(\mathrm{Cq}), 127.1(\mathrm{CH})$, $126.3(\mathrm{CH}), 125.1(\mathrm{Cq}), 119.2(2 \mathrm{CH}), 20.4\left(\mathrm{CH}_{3}\right)$; ESIMS $m / z$ : $1535.1\left([\mathrm{M}+\mathrm{Na}]^{+}, 100 \%\right)$.

Macrocycle $(\boldsymbol{R}, \boldsymbol{R})-\mathbf{1 2}$. The title compound was prepared by following the same procedure used for $\mathbf{1 0}$ but with $(R)-\mathbf{7}$ used instead of $(R)$-3. The crude product was purified by column chromatography $\left(\mathrm{CH}_{2} \mathrm{Cl}_{2} / \mathrm{AcOEt} 99: 1\right)$ to yield $(R, R)-\mathbf{1 2}(6 \mathrm{mg}$, $5 \%$ ). $[\alpha]^{25} \mathrm{D}+170^{\circ}\left(c 0.0015, \mathrm{CH}_{2} \mathrm{Cl}_{2}\right) ;{ }^{1} \mathrm{H} \mathrm{NMR}\left(\mathrm{CDCl}_{3}\right.$, $\left.300 \mathrm{MHz}, 25^{\circ} \mathrm{C}\right) \delta 10.44(\mathrm{~s}, 4 \mathrm{H}, \mathrm{NH}), 9.07$ (s, 4H, binaphthyl), 8.15 (d, 4H, binaphthyl), 7.78 (d, 8H, phenyl), 7.56 (t, 4H, binaphthyl), 7.45 (t, 4H, binaphthyl), 7.27 (d, 4H, binaphthyl), 7.02 (d, 4H, phenyl), 3.33 (s, 12H, O-CH $\left.)_{3}\right){ }^{13} \mathrm{C} \mathrm{NMR}\left(\mathrm{CDCl}_{3}\right.$, $\left.75 \mathrm{MHz}, 25^{\circ} \mathrm{C}\right) \delta 162.3(\mathrm{O}-\underline{\mathrm{CqON}}), 154.0(\mathrm{Cq}), 153.5(\mathrm{Cq})$, $135.2(\mathrm{Cq}), 134.5(\mathrm{CH}), 133.9(\mathrm{Cq}), 130.4(\mathrm{Cq}), 129.9(\mathrm{CH})$, $129.0(\mathrm{CH}), 126.0(\mathrm{CH}), 125.3(\mathrm{CH}+\mathrm{Cq}), 124.9(\mathrm{Cq}), 121.0$ $(2 \mathrm{CH}), 119.3(2 \mathrm{CH}), 62.0\left(\mathrm{OCH}_{3}\right)$; ESIMS $m / z: 1155.4$ $\left([\mathrm{M}+\mathrm{Na}]^{+}, 10 \%\right)$.

${ }^{1}$ H NMR complexation experiments. All spectra were recorded at $500 \mathrm{MHz}$ and at $298 \mathrm{~K}$. $K_{\mathrm{a}}$ values for the complexation of $(R, R)-12$ with $\left(n-\mathrm{Bu}_{4} \mathrm{~N}^{+}\right)_{2} \mathrm{X}^{2-}\left(\mathrm{X}^{2-}={ }^{-} \mathrm{O}_{2} \mathrm{C}\left(\mathrm{CH}_{2}\right)_{2} \mathrm{CO}_{2}{ }^{-}\right.$, $\left.{ }^{-} \mathrm{O}_{2} \mathrm{C}\left(\mathrm{CH}_{2}\right)_{3} \mathrm{CO}_{2}{ }^{-}\right)$were assessed by nonlinear treatment of the data obtained from ${ }^{1} \mathrm{H}$ NMR titration experiments. Samples were prepared by adding to a $0.5 \mathrm{~mL}$ solution of the host $(5 \mathrm{mM}$ in $\mathrm{CDCl}_{3}$ ) successive aliquots of a stock solution of the guest (62.5 $\mathrm{mM}$ in $\mathrm{CDCl}_{3}$ ), up to a final volume of $0.9 \mathrm{~mL}$. Eight values of $\delta_{\text {obs }}$ for the H-4 resonances were collected by keeping the [host] to [guest] ratio in the (1:0.25)-(1:10) interval. Nonlinear regression analysis of $\delta_{\text {obs }}$ versus [guest], using the WinEQNMR for Windows software package [47], provided the $K_{\mathrm{a}}$ value.

Molecular modeling. Geometry optimizations for the structures presented were carried out, first by using the semiempir- 
ical PM3 method, and then refined at the B3LYP/6-31G(d) level [48]. All calculations were performed at the Cineca supercomputer facility by using the Gaussian 09, Revision C.01 package [49].

\section{Supporting Information}

\section{Supporting Information File 1}

Additional NMR and MS spectra for the macrocyles, and Cartesian coordinates for the calculated geometries discussed in the paper.

[http://www.beilstein-journals.org/bjoc/content/ supplementary/1860-5397-8-109-S1.pdf]

\section{Acknowledgements}

Support from the University of Pavia, University of Messina, MIUR (Programs of National Relevant Interest PRIN grants 2004-033354 and 2009-A5Y3N9), the CINECA Supercomputer Center, with computer time granted by the ISCRA NANOCHIR project (HP10CKIGGH), and, in part, from CARIPLO Foundation (2007-2009) and INSTM-Regione Lombardia (2010-2012), is gratefully acknowledged.

\section{References}

1. Grave, C.; Schlüter, A. D. Eur. J. Org. Chem. 2002, 3075-3098. doi:10.1002/1099-0690(200209)2002:18<3075::AID-EJOC3075>3.0.C O;2-3

2. Yamaguchi, Y.; Yoshida, Z.-i. Chem.-Eur. J. 2003, 9, 5430-5440. doi:10.1002/chem.200305099

3. Höger, S. Chem.-Eur. J. 2004, 10, 1320-1329. doi:10.1002/chem.200305496

4. Zhang, W.; Moore, J. S. Angew. Chem., Int. Ed. 2006, 45, 4416-4439. doi:10.1002/anie.200503988

5. Hua, Y.; Ramabhadran, R. O.; Karty, J. A.; Raghavachari, K.; Flood, A. H. Chem. Commun. 2011, 47, 5979-5981. doi:10.1039/c1cc10428d

6. Pasini, D.; Ricci, M. Curr. Org. Synth. 2007, 4, 59-80. doi:10.2174/157017907779981606

7. Ghadiri, M. R.; Granja, J. R.; Buehler, L. K. Nature 1994, 369, 301-304. doi:10.1038/369301a0

8. Leclair, S.; Baillargeon, P.; Skouta, R.; Gauthier, D.; Zhao, Y.; Dory, Y. L. Angew. Chem., Int. Ed. 2004, 43, 349-353. doi:10.1002/anie.200352259

9. Fischer, L.; Decossas, M.; Briand, J.-P.; Didierjean, C.; Guichard, G. Angew. Chem., Int. Ed. 2009, 48, 1625-1628. doi:10.1002/anie.200804019

10. Pantos, G. D.; Pengo, P.; Sanders, J. K. M. Angew. Chem., Int. Ed. 2007, 46, 194-197. doi:10.1002/anie.200603348

11. Sakamoto, J.; Schlüter, A. D. Eur. J. Org. Chem. 2007, 2700-2712. doi:10.1002/ejoc.200700118

12. Xu, Y.; Smith, M. D.; Geer, M. F.; Pellechia, P. J.; Brown, J. C.; Wibowo, A. C.; Shimizu, L. S. J. Am. Chem. Soc. 2010, 132, 5334-5335. doi:10.1021/ja9107066
13. Gong, B. Acc. Chem. Res. 2008, 41, 1376-1386. doi:10.1021/ar700266f

14. Huc, I. Eur. J. Org. Chem. 2004, 17-29. doi:10.1002/ejoc.200300495

15. Sakai, N.; Mareda, J.; Matile, S. Acc. Chem. Res. 2008, 41, 1354-1365. doi:10.1021/ar700229r

16. Wenzel, M.; Hiscock, J. R.; Gale, P. A. Chem. Soc. Rev. 2012, 41, 480-520. doi:10.1039/c1cs15257b

17. Choi, K.; Hamilton, A. D. J. Am. Chem. Soc. 2003, 125, 10241-10249. doi:10.1021/ja034563x

18. Alfonso, I.; Bolte, M.; Bru, M.; Burguete, M. I.; Luis, S. V.; Rubio, J. J. Am. Chem. Soc. 2008, 130, 6137-6144. doi:10.1021/ja710132c 19. Pu, L. Chem. Rev. 1998, 98, 2405-2494. doi:10.1021/cr970463w 20. Brunel, J. M. Chem. Rev. 2005, 105, 857-898. doi:10.1021/cr040079g 21. Zhu, Y.; Gergel, N.; Majumdar, N.; Harriott, L. R.; Bean, J. C.; Pu, L. Org. Lett. 2006, 8, 355-358. doi:10.1021/ol0517168

22. Yan, P.; Millard, A. C.; Wei, M.; Loew, L. M. J. Am. Chem. Soc. 2006, 128, 11030-11031. doi:10.1021/ja0635534

23. Ma, L.; Mihalcik, D. J.; Lin, W. J. Am. Chem. Soc. 2009, 131, 4610-4612. doi:10.1021/ja809590n

24. Cornelis, D.; Franz, E.; Asselberghs, I.; Clays, K.; Verbiest, T.; Koeckelberghs, G. J. Am. Chem. Soc. 2011, 133, 1317-1327. doi:10.1021/ja104978t

25. Ricci, M.; Pasini, D. Org. Biomol. Chem. 2003, 1, 3261-3262. doi:10.1039/b310751p

26. Moletti, A.; Coluccini, C.; Pasini, D.; Taglietti, A. Dalton Trans. 2007, 16, 1588-1592. doi:10.1039/b700059f

27. Coluccini, C.; Castelluccio, A.; Pasini, D. J. Org. Chem. 2008, 73, 4237-4240. doi:10.1021/jo800315s

28. Coluccini, C.; Dondi, D.; Caricato, M.; Taglietti, A.; Boiocchi, M.; Pasini, D. Org. Biomol. Chem. 2010, 8, 1640-1649. doi:10.1039/b920867d

29. Coluccini, C.; Mazzanti, A.; Pasini, D. Org. Biomol. Chem. 2010, 8 , 1807-1815. doi:10.1039/b924400j

30. Caricato, M.; Coluccini, C.; Dondi, D.; Vander Griend, D. A.; Pasini, D. Org. Biomol. Chem. 2010, 8, 3272-3280. doi:10.1039/c004379f

31. Colombo, S.; Coluccini, C.; Caricato, M.; Gargiulli, C.; Gattuso, G.; Pasini, D. Tetrahedron 2010, 66, 4206-4211. doi:10.1016/j.tet.2010.03.102

32. Fujita, S.; Momiyama, M.; Kondo, Y.; Kagiyama, N.; Hori, S. H.; Toru, T. Anal. Chem. 1994, 66, 1347-1353. doi:10.1021/ac00080a022

33. Gramer, C. J.; Raymond, K. N. Org. Lett. 2001, 3, 2827-2830. doi:10.1021/ol016253u

34. Wuts, P. G. M.; Greene, T. W. Greene's Protective Groups in Organic Synthesis, 4th ed.; Wiley, 2006. doi:10.1002/0470053488

35. Yang, W.; Su, W.; Liu, D.; Wang, H.; Shen, J.; Da, C.; Wang, R.; Chan, A. S. C. Tetrahedron 2000, 56, 3511-3516. doi:10.1016/S0040-4020(00)00260-X

36. Saito, K.; Hirao, T. Tetrahedron 2002, 58, 7491-7501. doi:10.1016/S0040-4020(02)00828-1

37. Etter, M. C. Acc. Chem. Res. 1990, 23, 120-126. doi:10.1021/ar00172a005

38. Bhattacharya, S.; Nayak, S. K.; Chattopadhyay, S.; Banerjee, M.; Mukherjee, A. K. J. Phys. Chem. B 2003, 107, 13022-13028. doi:10.1021/jp0357370

39. Hunter, C. A.; Anderson, H. L. Angew. Chem., Int. Ed. 2009, 48, 7488-7499. doi:10.1002/anie.200902490 (example for a recent essay on cooperativity). 
40. Cram, D. J.; Helgeson, R.; Peacock, S. C.; Kaplan, L. J.;

Domeier, L. A.; Moreau, P.; Koga, K.; Mayer, J. M.; Chao, Y.;

Siegel, M. G.; Hoffman, D. H.; Sogah, G. D. Y. J. Org. Chem. 1978, 43, 1930-1946. doi:10.1021/jo00404a019

41. Asakawa, M.; Janssen, H. M.; Meijer, E. W.; Pasini, D.; Stoddart, J. F. Eur. J. Org. Chem. 1998, 983-986.

doi:10.1002/(SICl)1099-0690(199806)1998:6<983::AID-EJOC983>3.0. $\mathrm{CO} ; 2-\mathrm{W}$

42. Baret, P.; Beaujolais, V.; Gaude, D.; Coulombeau, C.; Pierre, J.-L. Chem.-Eur. J. 1997, 3, 969-973. doi:10.1002/chem.19970030619

43. Goodyer, C. L. M.; Chinje, E. C.; Jaffar, M.; Stratford, I. J.; Threadgill, M. D. Bioorg. Med. Chem. 2003, 11, 4189-4206. doi:10.1016/S0968-0896(03)00451-6

44. Nagle, P. S.; Rodriguez, F.; Kahvedžić, A.; Quinn, S. J.; Rozas, I. J. Med. Chem. 2009, 52, 7113-7121. doi:10.1021/jm901017t

45. Stock, H. T.; Kellogg, R. M. J. Org. Chem. 1996, 61, 3093-3105. doi:10.1021/jo952107o

46. Casas, J.; Nájera, C.; Sansano, J. M.; González, J.; Saá, J. M.; Vega, M. Tetrahedron: Asymmetry 2001, 12, 699-702. doi:10.1016/S0957-4166(01)00107-0

47. Hynes, M. J. J. Chem. Soc., Dalton Trans. 1993, 311-312. doi:10.1039/DT9930000311

48. Hehre, W. J.; Radom, L.; Schleyer, P. R.; Pople, J. A. Ab Initio Molecular Orbital Theory; Wiley: New York, 1985.

49. Gaussian, Revision C.01; Gaussian, Inc.: Wallingford, CT, 2009.

\section{License and Terms}

This is an Open Access article under the terms of the Creative Commons Attribution License

(http://creativecommons.org/licenses/by/2.0), which permits unrestricted use, distribution, and reproduction in any medium, provided the original work is properly cited.

The license is subject to the Beilstein Journal of Organic Chemistry terms and conditions:

(http://www.beilstein-journals.org/bjoc)

The definitive version of this article is the electronic one which can be found at: $\underline{\text { doi:10.3762/bjoc. } 8.109}$ 